\title{
Application of GIS Techniques for Assessment of Changes in Land Use Pattern and Environmental Impact of Mines over a Small Part of Keonjhar District of Orissa.
}

\author{
Mr. Sonjay Mondal ${ }^{1}$, Dr. Debashish Chakravarty ${ }^{2}$, \\ Dr.Jatisankar Bandayopadhyay ${ }^{3}$ \\ ${ }^{I}$ (Research scholar, Department. of Remote Sensing \& GIS, Vidyasagar University, West Bengal, India) \\ ${ }_{2}^{2}$ (Dr.Debashish Chakravatry, Associate Professor, Department. of Mining Engineering, Indian Institute of \\ Technology, Kharagpur-721302, West Bengal, India) \\ ${ }^{3}$ (Dr.Jatisankar Bandyopadhyay, Assistant Professor, Department. of Remote Sensing \&GIS, Vidyasagar \\ University, West Bengal, India )
}

\begin{abstract}
Mining activities and the waste products produced can have significant impact on the surrounding environment ranging from localized surface and ground water contamination to the damaging effects of airborne pollutants on the regional ecosystem. The long term monitoring of environmental impacts requires a cost effective method to characterize land cover and land cover changes over time. As per the guidelines of ministry of India, it is mandatory to study and analyze the impacts of mining on its surroundings the use of remote sensing technology to general valuable land cover maps is valuable asset to completing environment assessment over mining affected area.

Keywords- Mining, Airborne, Remote Sensing, Environmental Impacts.
\end{abstract}

\section{Introduction}

Mining tends to make a notable impact on the environment, the impact varying in severity depending on whether the mine is working or abandoned, the mining methods used, and the geological condition. It courses massive damage to landscape and biological communities of the earth. The unscientific mining of minerals possess a serious threat to the environment, resulting in the reduction of forest cover, erosion of soil in a greater scale, pollution of water, air and land and reduction in biodiversity. The problems of waste rock dumps become devastation to the landscape around mining areas (Sarma and Kushwaha, 2005).

The Indian sub continent is replete with minerals and many states have rich coal resources. Soon after independence, India witnessed a spurt in the growth of heavy industries that needed large amount of mining of iron and manganese. Thus the mining operations in India began on a large scale in 1950s. Presently, in India more than 80000 ha of land are under various types of mining.

Mining operations, which involve extraction of minerals from the earth crust, is second only to agriculture as the world's oldest and important activity. Since the history of mining is the history of the civilization from the prehistoric days man has been interested about earths minerals wealth. The crude stone implements of the early Paleolithic period. Post Neolithic pottery, the Egyptian pyramids, iron and manganese in various civilizations and the modern steel age are all testimony of mining activities of man. Natural resources gave been over exploited for almost two centuries, without any concern about environment.

\section{Study Area}

The study area is located between Latitude: $21^{\circ} 52.5^{\prime} 0^{\prime \prime}$ to $22^{\circ} 0^{\prime} 0^{\prime \prime} \mathrm{N}$ and Longitude: $85^{\circ} 22.5^{\prime} 0^{\prime \prime}$ to $85^{\circ} 30^{\prime} 0^{\prime \prime} \mathrm{E}$ in the Joda Block of Keonjhar District of Orissa. The study area is characterized by a high steep and rough terrain but an altitude changing from place to place. 


\section{II.1 Location Map of The Study}

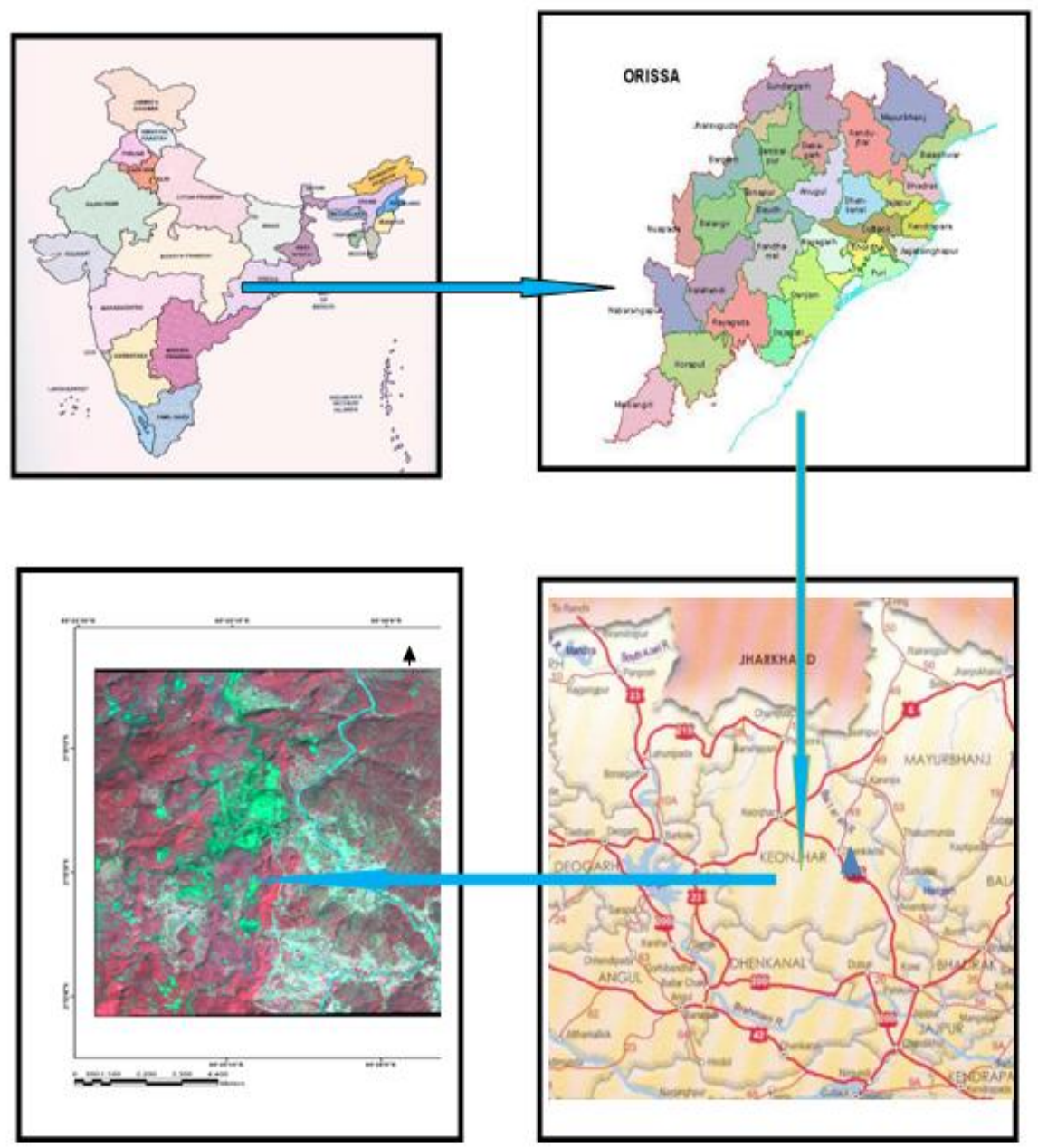

Figure 1: Location map of the study area.

\section{Aim \& Objectives Of My Study}

$>$ To categories the study area into environmental zones on the basis of the degree of environmental degradation.

$>$ To determine the present land use pattern;

$>$ Bringing a conclusion for optimizing the future land use pattern in light of upcoming mining activities in the study area and its associated impacts.

\section{Physiographic Setting}

The state is broadly divided into four geographical regions viz. the northern plateau, central river basins, eastern hills and coastal plains. The northern plateau region comprises mainly, Mayurbhanj, Keonjhar and Sundergarh districts. The central river basins lie between the northern plateau and eastern hills and include Bolangir, Sonepur, Sambalpur, Deogarh, Bargarh, Jharsuguda, Dhenkanal and Angul districts, and a part of Cuttack district. The eastern hills which constitute the last portion of the eastern ghats, lie to the south and southwest of central river basins stretching for about $250 \mathrm{~km}$ in northeast - southwest direction through the districts of Koraput, Rayagada, Nawarangpur, Malkangiri, Kalahandi, Nuapara, Gajapati and a part of Ganjam district. The eastern hills are elevated and are generally $900 \mathrm{~m}$ above sea level. (CHILIKA DEVELOPMENT AUTHORITY, state of Orissa, 2010)

\section{Geological Setting}

The physical features of the coastal regions of India are a sort of terra incognita. The coastal plains of Orissa are narrow in the north, wide in the middle, and narrow in the south (Sinha et al., 1971). Coastal Orissa is characterised by wide deltas. The monsoons are a great force in shaping the shore features. The ports on the east coast of India such as Ganjam, Kalingapatnam and others are protected by spits. The ports owe their existence to the projection afforded by bars and spits. The beach features work as natural breakwaters, providing relatively 
sheltered anchorage to these ports (Ahmad et al., 1972). Further, the rivers of Orissa have created large deltas at their confluence with the Bay of Bengal. The Mahanadi delta starts its projection on north east of Chilka Lake. The sediments brought by longshore drifting from the southwest during the Southwest monsoon, and currents or drifts are arrested in the Chilka lake. Starting from east there is a straight shoreline for about $120 \mathrm{~km}$ between the Mahanadi delta and Srikakulam. There are only two marine inlets within these long stretches, one at the narrow mouth (400-600 m) of the Chilka lake and the other on the mouth of the Rushikulya river. Chilka lake is located on the southwest corner of the Mahanadi delta and connected with the sea through a tidal inlet. It has wide sandy beach ridges and barrier spits which separates it from the Bay of Bengal.

\section{Outline of the Study}

Responding to the above stated situation, first we selected possible long-term factors which may impact on a long-term change of national land use pattern, and then reviewed the long-term forecasts of those possible factors from researches conducted by the international organizations: the world population change, urbanization, supply-demand balance of agricultural products and energy in the world.

\section{Earlier work done on this area}

- The land under permanent pasture has also decreased.

- Fallow land -left without cultivation far one or less than one agricultural year.

- National forest policy in 1952.

- Waste land includes rocky. Arid and desert area and land put to other non agricultural uses included settlements, roads railways industry etc.

- Continuous use of land over a long period of time out taking appropriate measures to conserve and manage it.

But the field work carried out between 1982 and 1986 in the Keonjhar district of Orissa State. very little work has been done previously on the pre history of this area, and fieldwork reported here ,carried out in part fulfillment of my doctoral work, here the initial aim of locating stone age sites through intensive exploration and then making a detailed study of their associated environment and land use pattern.

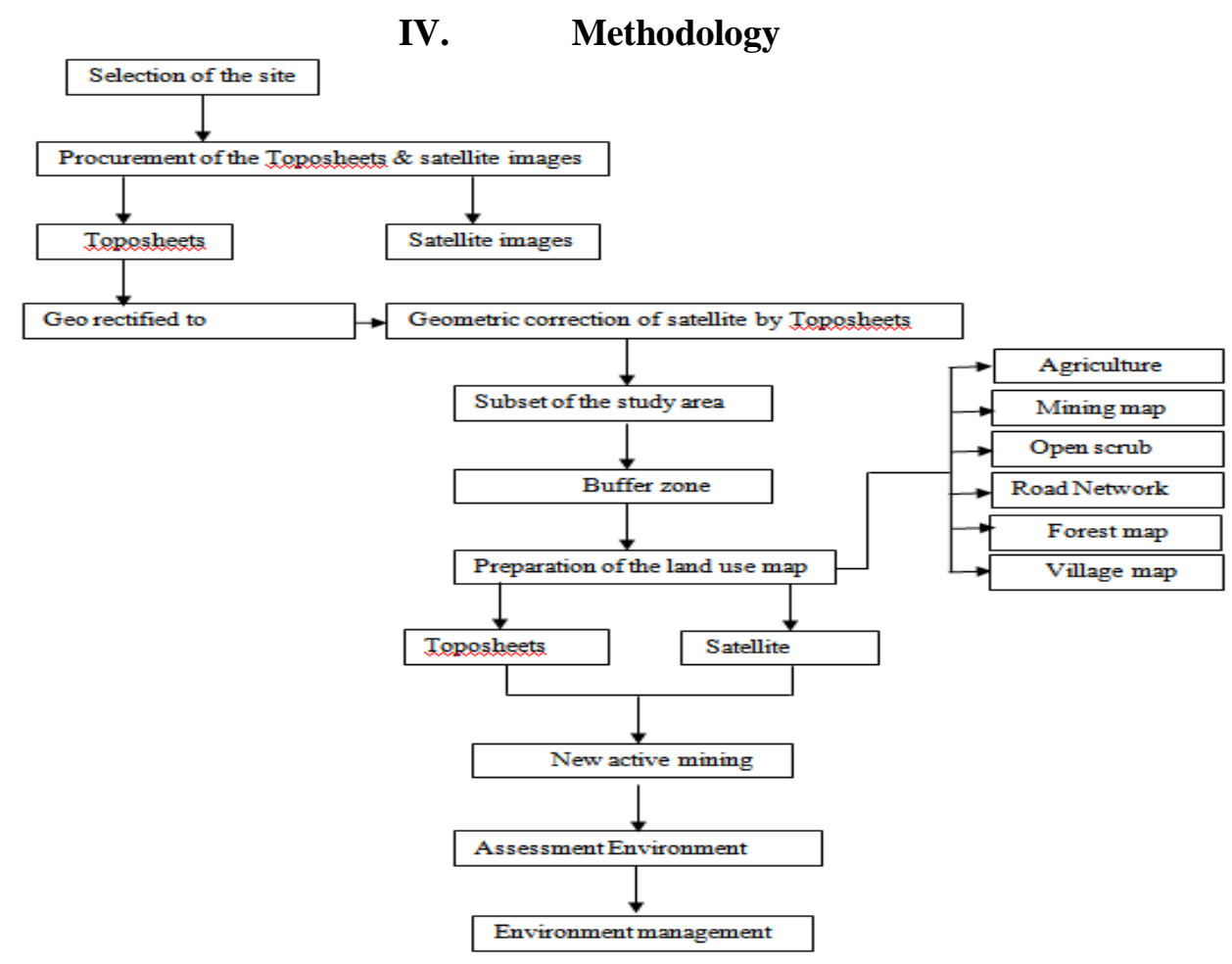

Selection of mine site: Keonjhar District is the one of the important iron mineral in the Orissa state. Mining stated from 1976 in along 30 years has changes in the environment and surrounding covered the pollution, so the environmental purpose has to be measured or calculated

Selection of the study area and get to the all the primary details. Digitized the mining boundaries by the geo rectified toposheets and superimpose the Environment planning. The buffering zone is prepared in the Arc GIS software. Prepared the area of interest (AOI) from the satellite images as shown in the Figure no 18. 
The Division buffering zone form the satellite images are to be classified by the ERDAS SOFTWARE using. By the field verification /ground tooth prepared a land use and land cover data base is prepare .The error matrices from the supervised classified image and field verification for the kappa statistics. Calculate / analysis the attribute of the individual classes in the buffer zone in satellite image. Final attribute are prepared for a land use and verified the classes by the field verification, spatial and spectral matching also. As per the requirements land use pattern map finally prepare.

\section{Data used:}

Table 1: Table for data

\begin{tabular}{|l|l|}
\hline $\begin{array}{l}\text { Remote } \\
\text { Sensing Data }\end{array}$ & $\begin{array}{l}\text { Landsat ETM+ } \\
\text { Satellite image } \\
\text { Google Earth image }\end{array}$ \\
\hline $\begin{array}{l}\text { Co-lateral } \\
\text { Data }\end{array}$ & $\begin{array}{l}\text { Toposheets } \\
\text { Regional maps }\end{array}$ \\
\hline
\end{tabular}

1. Primary date collected from the mining Agency(Mine Planning, local /regional maps)

2. Toposheets have collected from the Geological survey of India in 1:50,000 scale.

3. Regional maps (Geology, Geo morphological and previous land use maps).

4. Satellite image collected glcf site.

a. Land sat ETM+ Satellite image (date, 26-10-2001).

b. Google image.

\section{The role of land-use:}

a. Human systems depend critically on the state of the environment. Managing a sustainable evolution of land-use systems at the regional scale concerns various themes of vital importance:

b. Land-use/cover changes affect the hydrological cycle both qualitatively and quantitatively by influencing how precipitation is intercepted, evapotranspired, and retained in soils, which in turn determines the amount and speed of runoff. Land-cover change also influences local soil erosion and nutrient losses. At the scale of river basins, it determines water availability and the intensity and frequency of flooding;

c. Ecosystems and land in general store waste materials and provide critically important purification functions. The ability to provide these services is threatened by pollution and land degradation due to inappropriate land use, or over-exploitation that transgresses capacity thresholds. (options summer, 1999)

\section{Environmental factor}

- Eco-System Management

- Air/Water Pollution Control

- Water Resource Management

- Flora/Fauna Conservation and Management

- Land Use Planning

- Social Sciences/Rehabilitation

- Project Appraisal

- Ecology

- Environmental Health

- Subject Area Specialists

- Representatives of NGOs/Persons Concerned With Environmental Issues

So land use planning is the important part of my project work, so I highly indicate the land use pattern and there environmental impact. 


\section{Impacts on land use:}

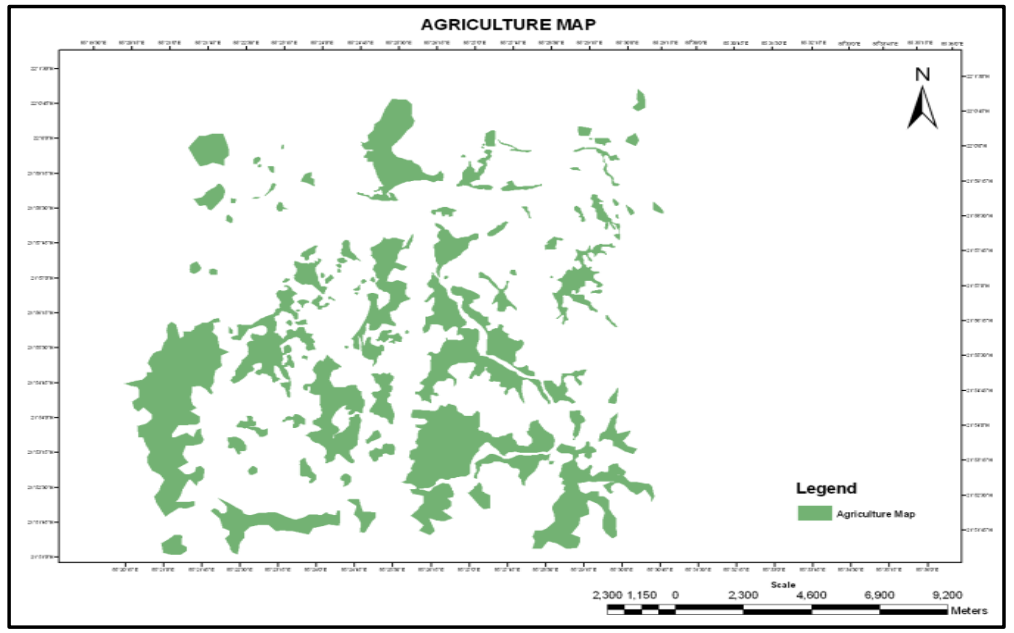

Figure 3: Agricultural map of the study area.

There might be a considerable impact on the land in my study area but the mining activities as there are a lot of mines in and around this area. However, the economic needs of the local people who are economically backward are being met to a large extent. Considering the existing Agro-climatic conditions, in future there may be very little possibility for any change in the present land use pattern. Keonjhar district occupies an important place in the mineral resource map of eastern India. High quality of iron \& manganese ore deposits are found to be located under large tracts of forestland, rich in bio-diversity \& water catchment areas of Baitarani River one of the large river of state. The forest land of Keonjhar constitutes one of the major parts of forest resource of Orissa. Apart from this, it is home to a sizeable tribal population; includingsome of the most primitive tribes, those who are totally dependent on forests and agriculture for their livelihoods and survival. They live in conditions of subsistence dependence on agriculture.

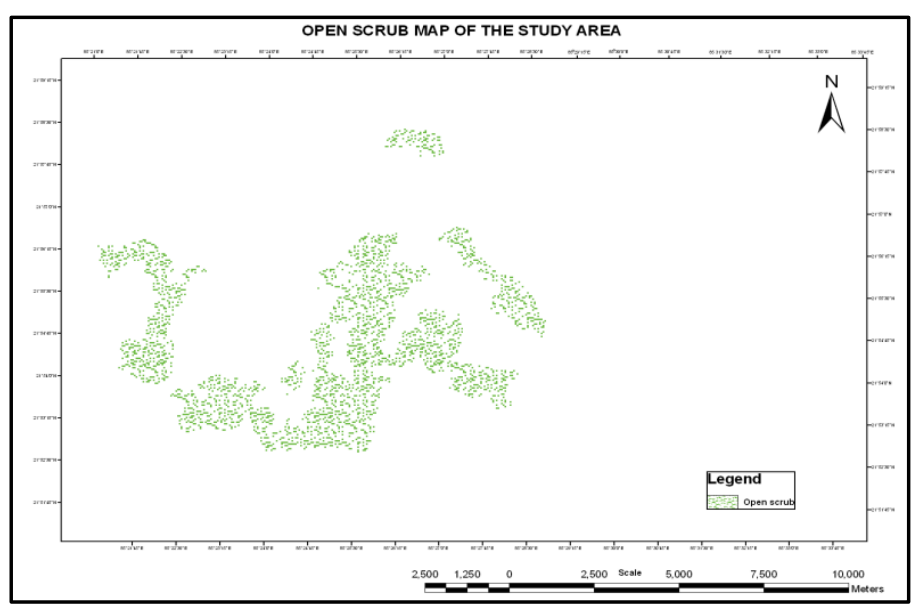

Figure 4: Open scrub map of the study area.

The land use pattern shows that Open scrub land cover constitutes second highest type followed by land with scrubs. It is not dominant at all in any stage in the site of scrub forest where mining is imminent at any point of time. 


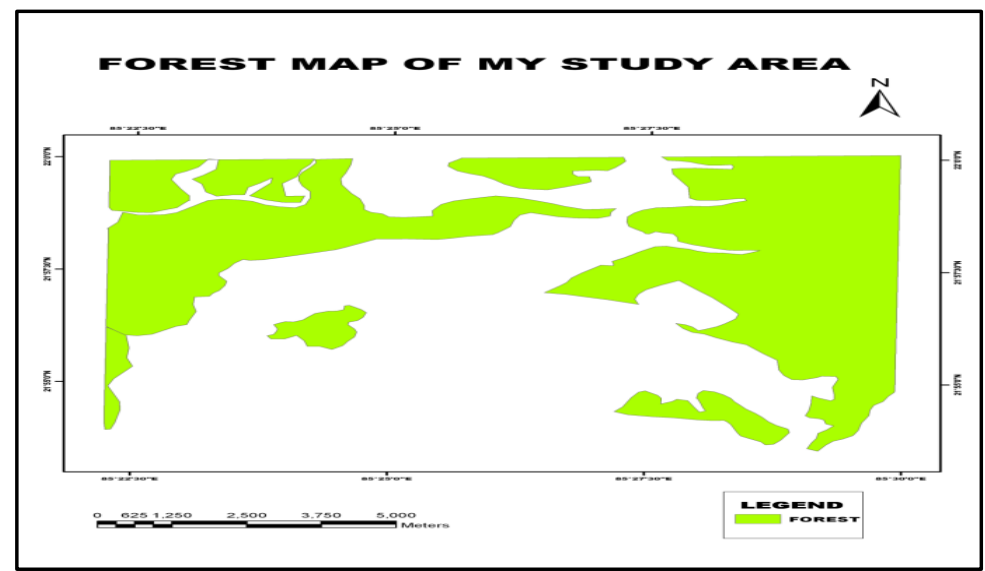

Figure 5: Forest map of the study area.

It may be due to large scale of deforestation and vehicular movement. Similarly change in land scape is resulting in to affecting the solar radiation thus increasing the temperature. Apart from it, reduction in green cover is the major reason in alternation of this. Another reason of this air quality may be because of presence of dense forest in the study area. It has been found out that forest comprises more than $50 \%$ of land use cover of the study area which acts as sink for any sort of air pollution

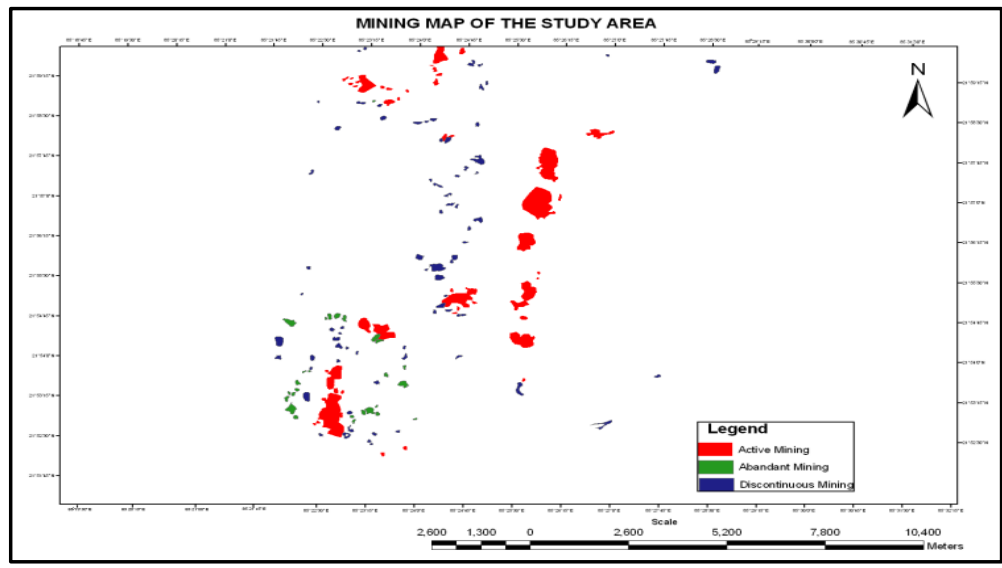

Figure 6: Mining map of the study area.

Above showing the features, there are three type of mining located in the area.

Active Mining

$>$ Abandant Mining

$>$ Discontinuous mining

The big area covered by active mining that continue speeded in sounding area but in mining of abandant that quite low located in the area and lastly discontinues mining has been showing the lower part of active mining.

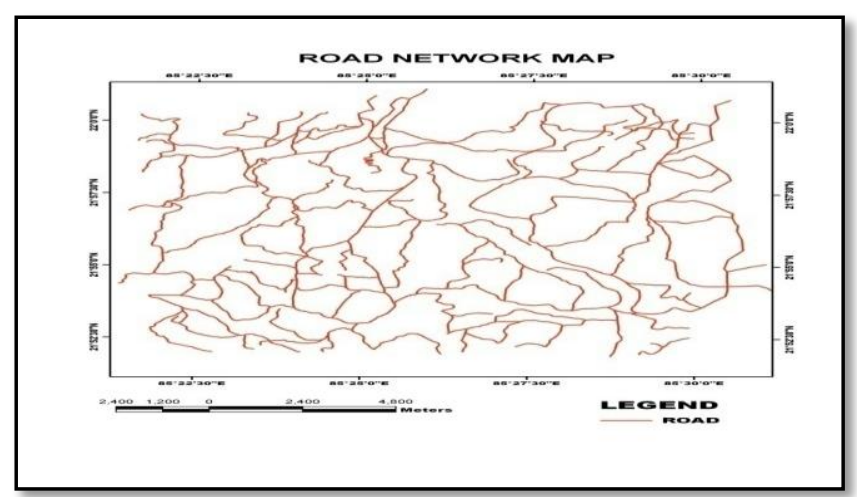

Figure 7: Road network map in the study area. 
The area can be approached from Keonjhar town covering a distance of $56 \mathrm{KM}$ road consisting of $7 \mathrm{~km}$ on NH 215 (Panikoili-Keonjhar Kalta) and $49 \mathrm{Km}$ all weather roads between NH215and Srikagutu on Palaspanga- Bamberi road.

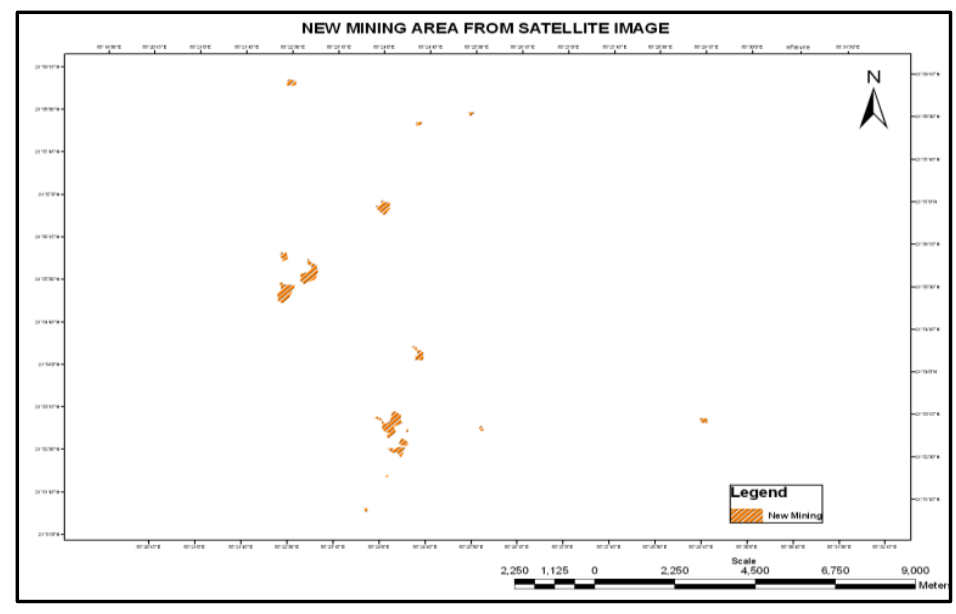

Figure 8: New mining of the study area.

Land use pattern is change in the new mining area which is shown in the figure (fig7). But this area is manly mining activity area. Spatial changes of mining area are also observed. From the Toposheet of 1975 it is observed that mining activity in the area was very small and scattered but now we observe that various land use changes in the new mining area.

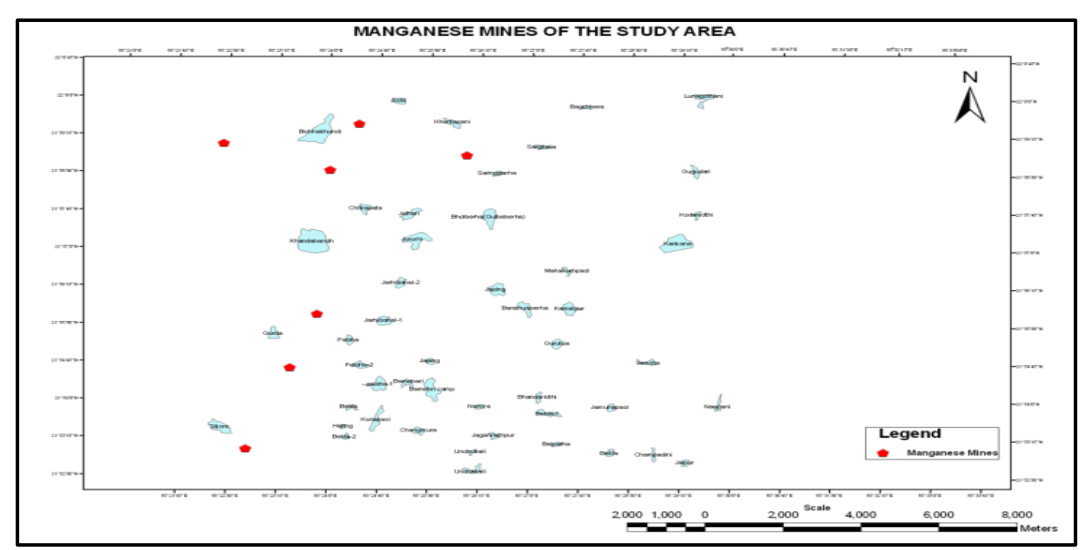

Figure 9: Manganese mines of the study area.

There manganese mines are red indicate above this images and the nearest villages covered in the surrounding mining. Basically manganese mining is not showing high level but iron mining are lot of cover in the keonjhar area

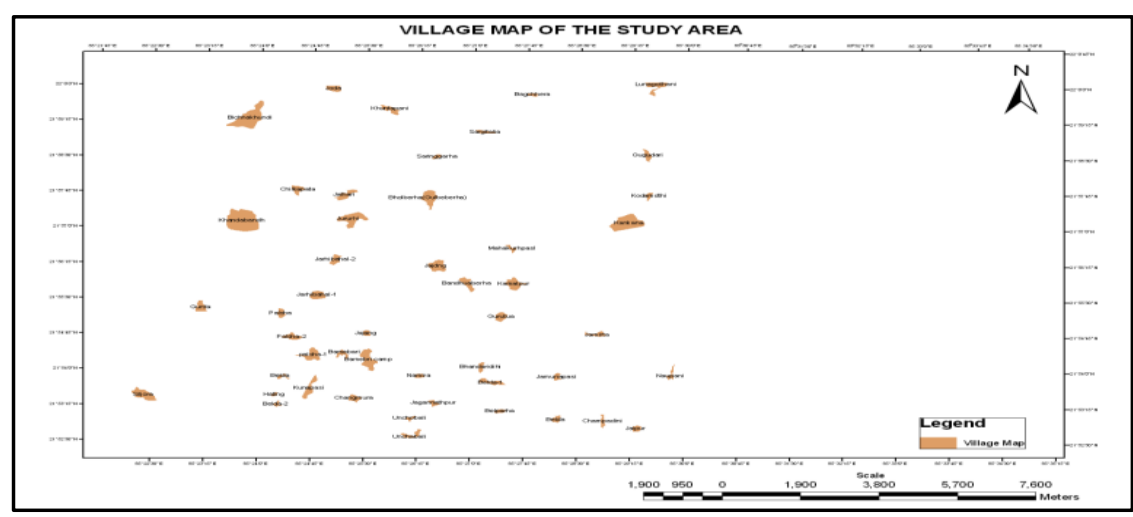

Figure 10: Village map of the study area. 
Villages are showing above the images and its located and surrounding the mining zone has spading much polluted the hole area.

\section{Use of Minerals}

The ore produced from the mines are entire sold in domestic market and the size specification of the iron depends on the requirement of customer. A sponge iron plant in the stay in the near place. So which is managed the iron from the place. Iron are produced will be consumed for captive use in the sponges plant mainly for internal consumption in steel making shop.

\section{Impacts due to transportation of the mineral}

Impact on existing environment \& Local infrastructure

$>$ Major impact is Dust Generation

$>$ Increase in Gaseous Pollutants like SO2, NOx

Noise Pollution Control measures

$>$ Installation of Dust Suppression System \& Regular Water Sprinkling on haul roads

$>$ Proper maintenance of Transportation vehicles

$>$ Checking up for overloading of Transportation vehicle.

$>$ Regular Air Quality Monitoring to check increment of pollutants.

Open cast mechanized method of mining is being adopted with the benching pattern of $6 \mathrm{~m}$ height $\mathrm{x} 6 \mathrm{~m}$ width. It involves deployment of machines like Wagon drill, excavator and development also followed by drilling,blasting, excavation, transportation, communication, sorting, sizing blending and dispatch

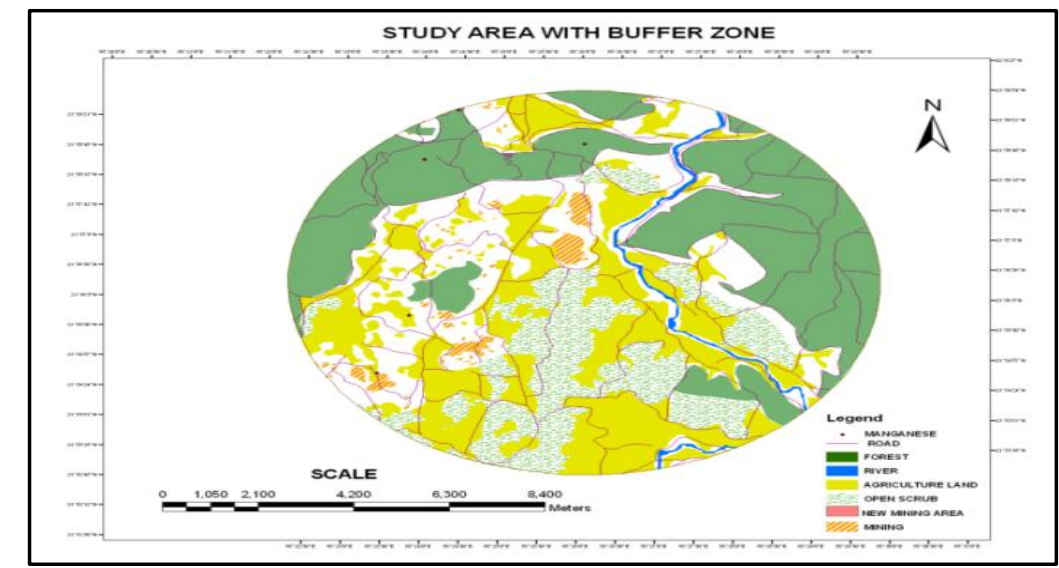

Figure 11: 18km buffer is prepared around the Joda block to delineate the impact area.

\section{IV.1 Existing Manpower}

The mine is working with adequate number of management and technical personnel with the anticipated production of next five years. There is scope of further increase in the management and supervising manpower along with the miners and the hazri workers. Including Managerial, Skilled, Unskilled Personnel \& laborers.

\section{IV.2 Land degradation}

Open cast mining causes various types environmental pollution. It is predicted that the process of mining have little impact on the existing ecological conditions of the project area. The increase in production in mine and other allied activities in the area shall have additional impact on abiotic and biotic environment of the area (although not significant) various environmental safe guards have been proposed to implement in the form of my study area report.

\section{IV.3 Environmental Concerns}

Open cast mining causes various types environmental pollution. It is predicted that the process of mining have little impact on the existing ecological conditions of the my study area.The increase in production in mine and other allied activities in the area shall have additional impact on abiotic and biotic environment of the area (although not significant) Various environmental safe guards have been proposed to implement in the form of my study area report. 


\section{IV.4 Description of the environment}

Meteorological data have been collected at the pre-defined station located in the study area.

Meteorological data such as Rainfall, Temperature, Humidity, Wind speed \& Wind Direction have been generated as the primary data. Secondary data on meteorology have also been collected from the nearest station i.e. Keonjhar.

\section{IV.5 Climate}

The area experiences dry to moist subtropical climate with summer from March to May and monsoon from June to August. May is the hottest month and December to January is colder months.

But the average annual rainfall recorded for the last twelve years $(1990-2001)$ in the region is 1366.78 $\mathrm{mm}$. The annual rainfall recorded during last couple of years is in the range of $1200-1400 \mathrm{~mm}$. On an average $90 \%$ of rainfall is received during monsoon from June to August. Similarly Maximum rainfall recorded is 537.68 $\mathrm{mm}$ during July, 1990. The maximum temperature of $39.460 \mathrm{C}$ is found to be in the year 1994, while the minimum temperature of $12.70 \mathrm{C}$ is recorded during in 1992.

Temperature recorded from the Meteorological station fixed in the study area during the study period indicates that the temperature ranged from 22.1 to 44.20C during March 2009 to May 2009.

Table 2: climate parameters

\begin{tabular}{|l|l|l|}
\hline \multirow{4}{*}{ Item } & \multicolumn{1}{|c|}{ Parameters } & \multicolumn{1}{c|}{ Particulars } \\
\hline \multirow{4}{*}{ Rainfall } & Range & $\begin{array}{l}758 \text { to } 1580 \mathrm{~mm} \text {, as recorded over a period } \\
\text { of 22 years. }\end{array}$ \\
\cline { 2 - 3 } & Annual average & $\begin{array}{l}1270 \mathrm{~mm} \\
\text { Mote then } 70 \% \text { of the rain occurs during the } \\
\text { monsoon season, i. e .June to September }\end{array}$ \\
\hline $\begin{array}{l}\text { Temperature range } \\
\text { (monthly mean of daily } \\
\text { temperature ) }\end{array}$ & Minimum & $5.5^{0} \mathrm{C}$ (Nov. 1996) \\
\cline { 2 - 3 } & Maximum & $43.1^{0} \mathrm{c}$ (April, 1999) \\
\hline $\begin{array}{l}\text { Relative humidity range } \\
\text { (monthly mean of daily } \\
\text { RH ) }\end{array}$ & Minimum & $31 \%$ \\
\cline { 2 - 3 } & Maximum & $88 \%$ \\
\hline $\begin{array}{l}\text { Wind speed range } \\
\text { (monthly mean of daily } \\
\text { wind speed) }\end{array}$ & Max at 8:30 hr & $6 \mathrm{~km} / \mathrm{hr}$ \\
\cline { 2 - 3 } & Min at 8:30 hr & $2 \mathrm{~km} / \mathrm{hr}$ \\
\cline { 2 - 3 } & Max at $17: 30 \mathrm{hr}$ & $8 \mathrm{~km} / \mathrm{hr}$ \\
\cline { 2 - 3 } & Min at 17:30 hr & $1 \mathrm{~km} / \mathrm{hr}$ \\
\hline
\end{tabular}

Long term meteorological data collected from IMD, (Indian meteorological Department) Bhubaneswar for Angus IMD station has been referred for preparation of the above table:

But the site specific continuously monitored micro meteorological data through autographic instrument for one full post monsoon season, (2010 march) have been summarized in the following tables.

Table 3:Site Specific Micro meteorological Data for Wind Speed and Temperature

\begin{tabular}{|l|l|l|l|l|l|l|l|}
\hline Month & \multicolumn{3}{|c|}{ Wind } & \multicolumn{4}{c|}{ Temperature } \\
\cline { 3 - 7 } & Speed & Mean & Max & $\begin{array}{l}\text { \% of } \\
\text { Calm }\end{array}$ & $\begin{array}{l}\text { Mean (Dry } \\
\text { Bulb ) }\end{array}$ & Highest & Lowest \\
\cline { 5 - 8 } & & & & Max & Min & & \\
\hline October & 3.60 & 47.88 & 23.13 & 42.50 & 24.60 & 36.20 & 24.20 \\
\hline November & 3.87 & 25.92 & 20.69 & 32.80 & 16.70 & 33.70 & 13.30 \\
\hline December & 4.82 & 30.24 & 0.00 & 29.80 & 13.80 & 30.60 & 13.30 \\
\hline
\end{tabular}

Table 4: $\square$ Site specific Micro meteorological Data for Relative Humidity and Rainfall

\begin{tabular}{|c|l|l|l|l|l|l|}
\hline \multirow{2}{*}{ Month } & \multicolumn{5}{|c|}{ Relative Humidity (\%) } & \multicolumn{3}{|c|}{ Rainfall (mm) } \\
\cline { 2 - 7 } & Mean & Highest & Lowest & Total & $\begin{array}{l}\text { No. of rainy } \\
\text { Highest } \\
\text { days }\end{array}$ \\
\hline October & 84.03 & 99.90 & 41.60 & 170 & 14 & 12 \\
\hline November & 62.68 & 99.90 & 20.80 & 00 & 00 & 00 \\
\hline December & 59.46 & 99.80 & 23.20 & 00 & 00 & 00 \\
\hline
\end{tabular}


Wind rose diagrams prepared on the basis of hourly micro meteorological data for post monsoon season 2009 (October 2009 to December 2005) are given for daytime, night time in respectively.

(A) Figure for Relative Humidity.

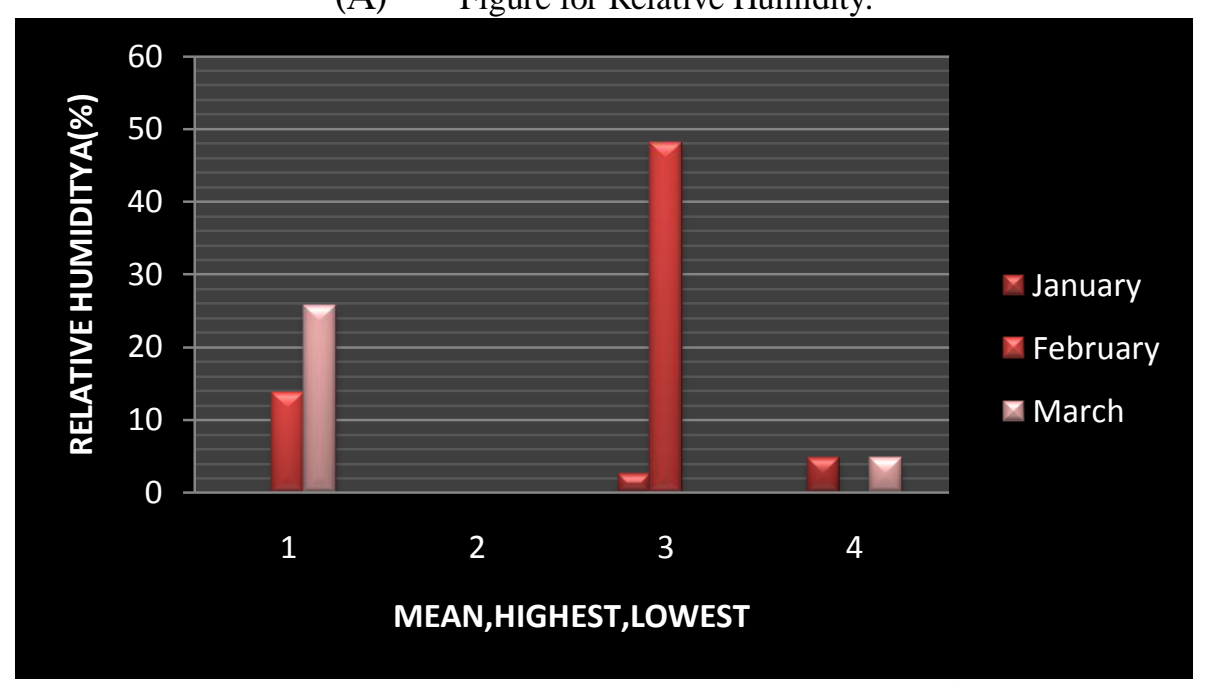

(B) Figure for Rainfall

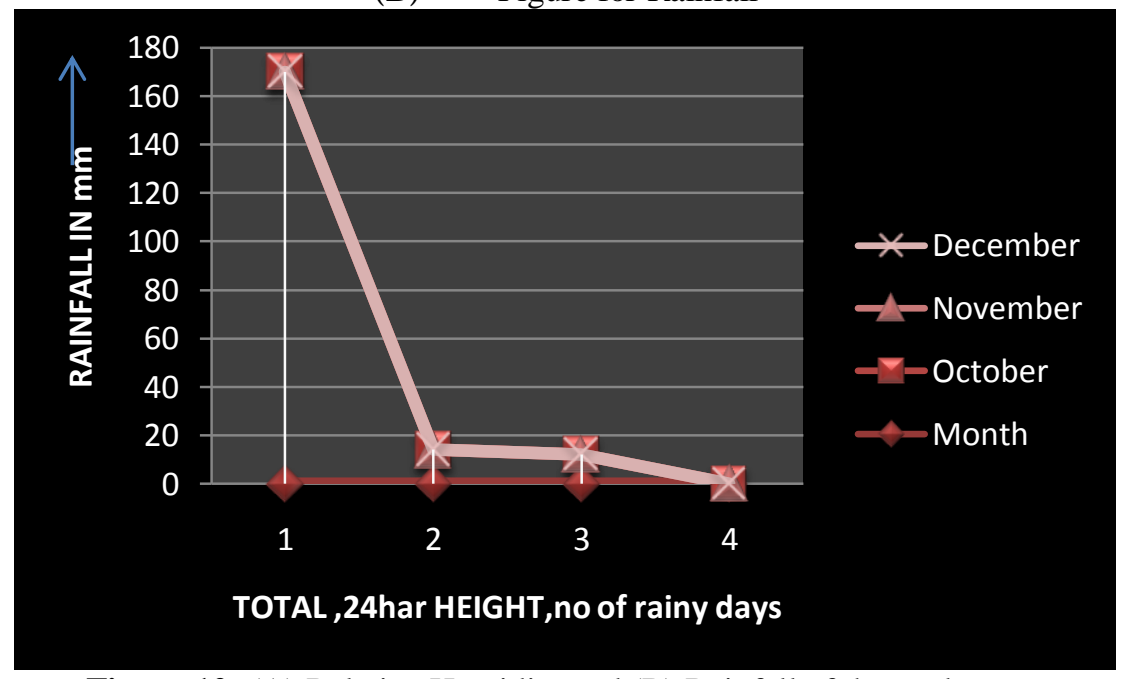

Figure 12: (A) Relative Humidity and (B) Rainfall of the study area.

Table 5: Weather data for the year of the region

\begin{tabular}{|c|c|c|c|c|c|c|c|c|c|c|c|}
\hline \multirow[t]{2}{*}{ Month } & \multicolumn{2}{|c|}{$\begin{array}{l}\text { Temperature } \\
(0 \mathrm{c})\end{array}$} & \multicolumn{3}{|c|}{ Relative humidity (\%) } & \multicolumn{3}{|c|}{$\begin{array}{l}\text { Wind speed } \\
(\mathrm{mtr} . / \mathrm{sec})\end{array}$} & \multicolumn{3}{|c|}{$\begin{array}{l}\text { Wind direction } \\
\text { (degree) }\end{array}$} \\
\hline & Max & Min & Max & Min & Avg & Max & Min & Avg & Max & Min & Avg \\
\hline January & 33.40 & 11.90 & 98.60 & 62.20 & 62.20 & 7.10 & 0.20 & 3.20 & 321 & 164 & 187 \\
\hline February & 41.90 & 12.80 & 75.90 & 60.20 & 60.20 & 5.40 & 0.10 & 2.20 & 342 & 175 & 233 \\
\hline March & 44.80 & 17.60 & 81.40 & 58.60 & 58.60 & 15.30 & 0.20 & 4.20 & 326 & 74 & 102 \\
\hline April & 44.80 & 19.90 & 82.60 & 66.80 & 66.80 & 11.00 & 0.40 & 5.20 & 355 & 74 & 195 \\
\hline May & 47.80 & 20.00 & 90.30 & 58.50 & 68.50 & 7.80 & 0.30 & 2.80 & 302 & 42 & 242 \\
\hline June & 48.20 & 22.60 & 81.60 & 74.20 & 74.20 & 15.20 & 0.20 & 10.20 & 339 & 26 & 174 \\
\hline July & 38.70 & 23.30 & 99.50 & 80.50 & 80.50 & 10.40 & 0.40 & 8.30 & 342 & 13 & 210 \\
\hline August & 38.30 & 23.90 & 100.00 & 80.20 & 80.20 & 7.50 & 0.60 & 6.80 & 389 & 65 & 272 \\
\hline September & 40.50 & 26.20 & 92.60 & 78.20 & 78.20 & 8.80 & 0.20 & 5.20 & 371 & 134 & 138 \\
\hline October & 36.80 & 22.70 & 92.10 & 70.40 & 70.40 & 7.40 & 0.40 & 6.20 & 314 & 81 & 142 \\
\hline November & 32.50 & 13.30 & 98.10 & 62.00 & 62.00 & 7.30 & 0.50 & 4.20 & 333 & 115 & 188 \\
\hline December & 32.90 & 9.10 & 98.10 & 70.80 & 70.80 & 5.80 & 0.20 & 6.20 & 320 & 74 & 226 \\
\hline
\end{tabular}


Table 6:YEARLY RAINFALL DATA

\begin{tabular}{|c|c|c|c|c|c|c|c|c|}
\hline \multirow[b]{2}{*}{ Month } & \multicolumn{5}{|c|}{ YEARLY RAINFALL DATA (mm) } & \multirow[b]{2}{*}{2003} & \multirow[b]{2}{*}{2004} & \multirow[b]{2}{*}{2005} \\
\hline & 1998 & 1999 & 2000 & 2001 & 2002 & & & \\
\hline January & 0.0 & 0.0 & 2.4 & 4.6 & 7.5 & 0.0 & 24.4 & 23.2 \\
\hline February & 13.6 & 0.0 & 48.1 & 0.0 & 1.9 & 19.0 & 9.6 & 0.5 \\
\hline March & 25.6 & 0.0 & 0.0 & 4.6 & 2.0 & 13.7 & 29.6 & 41.2 \\
\hline April & 12.1 & 0.0 & 2.0 & 0.0 & 41.5 & 11.8 & 33.7 & 35.8 \\
\hline May & 13.4 & 2.9 & 81.2 & 0.0 & 71.6 & 35.6 & 114.9 & 21.6 \\
\hline June & 87.5 & 152.3 & 83.4 & 25.5 & 107.9 & 254.1 & 155.4 & 167.0 \\
\hline July & 72.1 & 206.4 & 128.2 & 714.7 & 28.9 & 319.3 & 352.2 & 668.8 \\
\hline August & 207.7 & 191.1 & 288.7 & 465.1 & 409.5 & 312.2 & 246.6 & 160.3 \\
\hline September & 167.5 & 255.5 & 176.4 & 101.3 & 133.2 & 326.4 & 109.6 & 212.4 \\
\hline October & 62.3 & 336.3 & 0.0 & 57.9 & 6.7 & 370.6 & 262.6 & 193.8 \\
\hline November & 31.8 & 10.2 & 0.0 & 8.0 & 5.80 & 17.8 & 0.0 & 0.3 \\
\hline December & 693.6 & 4.8 & 0.0 & 0.0 & 0.0 & 30.2 & 0.0 & 0.1 \\
\hline total & 693.6 & 1159.5 & 810.4 & 1381.7 & 816.5 & 1710.7 & 1338.6 & 1525.0 \\
\hline
\end{tabular}

Source: district statistical handbook

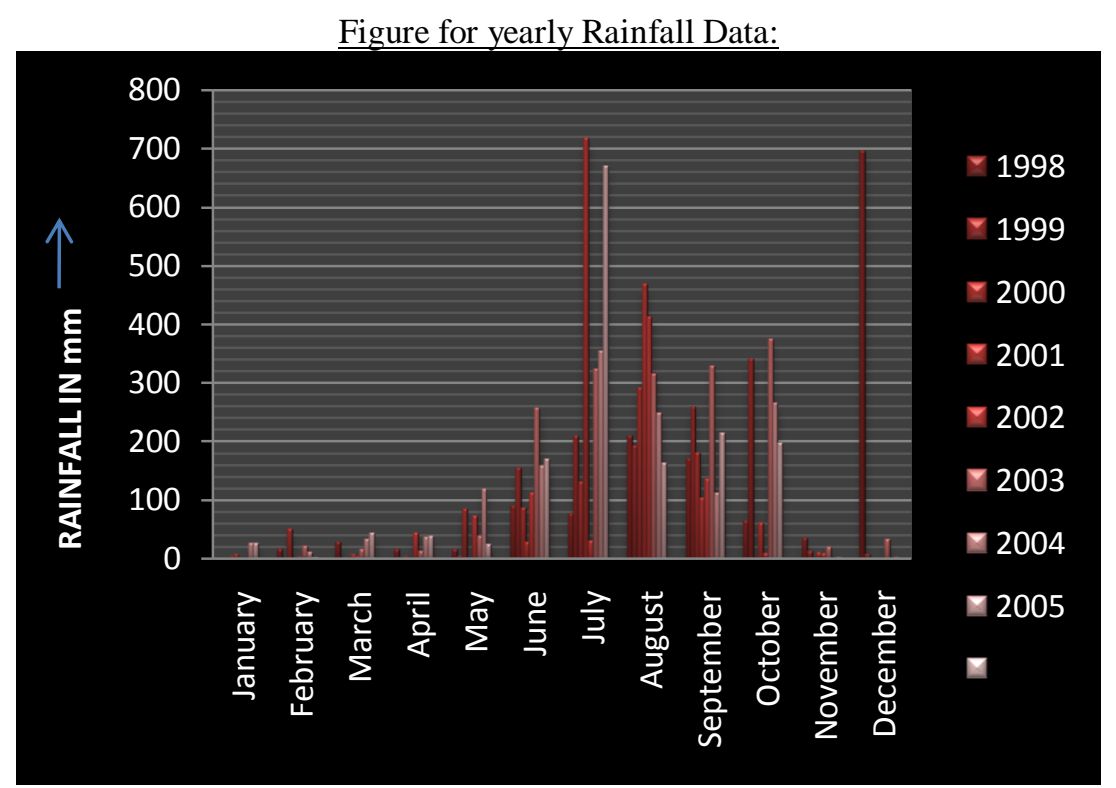

Figure 13: Yearly Rainfall data in the study area.

\section{IV.6 Wind speed and direction}

The data on wind speed and wind direction have been collected during the study period. Wind direction and Wind speed play a vital role to disperse the containment of dust in the local surrounding in the transportation of dusts. The maximum wind speeds recorded during the study period were $18.6 \mathrm{Km} / \mathrm{hr}$ during the study period. Predominant wind direction is SW-SE. Daily data have been collected and a wind rose diagram has been prepared.

\section{V.1 Impact on Flora:}

\section{Impact on biodiversity}

The floral population in the core zone is very less. The lease comprises of forest land but the mining is confined to the broken up area \& hence there will be no impact on the Floral Population within the area zone. The flora is likely to be affected as there are a cluster of mines around the mining area. Sal, Kendu, Mahul are the most dominant species in the forest in this region. Other plant species found are mainly Sisham, Bahada, Arjun, Kusum.

\section{V.2 Impact on Fauna:}

No endangered animals are found within the study area. But there will be some impact on the faunal diversity in the area due to heavy frequency of the mines in the study area. As this region is thick in forest cover, animal inhabitants are also found in the regions which are mainly Elephant, Bear, Jackal, Monkey etc. 


\section{V.3 Impact of ground vibration}

During mining operations vibration is generated from various sources like transportation vehicle, equipment \& machineries etc. Blasting operation not only cause vibration but also air blast. Among these, vibration and air blast from the blasting is most significant, as it has potential to cause community concern. The vibration and air blast from blasting can lead to community concern primarily due to fear of structural damage.

V.4 Risk assessment \& management

Following hazards may occur during the course of mining

- $\quad$ Fire hazards

- $\quad$ Slope instability

- $\quad$ Erosion and sedimentation

- $\quad$ Road Accidents

- $\quad$ Falling of boulders

- $\quad$ Blasting hazards

Following procedures will be followed for effective management of any disaster in the mine.

Step - 1: $\quad$ Identification of Disaster risk

Step $-2: \quad$ Identification of persons at risk

Step - 3: $\quad$ Removal of hazard

Step $-4: \quad$ Evaluation of the risk

Step - 4: $\quad$ Control measures to be taken

Step - 5: $\quad$ Maintaining Assessment records

Step $-6: \quad$ Review

\section{Environment management plan}

\section{VI.1 Measures for controlling air pollution}

Regular water spraying on haul roads. The volume of dust rising from waste dump areas \& ore, roads, etc. by action of wind shall be checked by planting grasses and broad leaf trees. Ensuring transporting vehicles not to cross stipulated speed. Exhaust fumes in the internal combustion engines used in excavators, dumpers, dozers and other machinery shall be minimized by ensuring vigorous maintenance and stringent overhaul schedules.

\section{VI.2 Measures for controlling water pollution}

Proper drainage system shall be done within the study site. There will be no effluent discharge from the project site, so the chance of water pollution is negligible. Appropriate measures shall be taken to ensure that the surface water quality in the project area is within permissible limits. Before water is supplied for consumption particularly for drinking purpose it has to be ensured that the water is free from any pathogens.

\section{VI.3 Solid Waste Management}

The waste generated during conceptual mining period will be in the tune of 62.292 lakhs cum, out of which 37.375 lakhs cum of materials shall be used for construction of road, Railway siding and reclamation of quarry and the remaining 24.917 lakhs cum shall be dumped south-eastern side and western side of the lease area as ear marked in the conceptual plan. This will cover an area of 20 hects. But I mention to only small part of my study area.

\section{VI.4 Occupational safety and health}

To avoid any adverse effect on the health of workers due to dust, noise and vibration etc. extensive measures has to be adapted related to safety aspect. Regular maintenance and testing of all equipments \& machineries as per manufacturer's guidelines. Periodical medical examination of all workers by medical specialists shall be conducted.

\section{VI.5 Socio economic measures}

The work, does not involve any displacement of human habitation, hence no habilitation package is needed for displacement. The activity envisages the deployment of local laborers. So, it is likely that the general economic condition of the local people will improve. The peripheral development package will also improve their health and sanitation. Health and education facilities created in the project shall be extended to villagers also. Roads development in the project shall be utilized by the villagers. Providing employment to local people will be the major factors for upliftment of the society. 

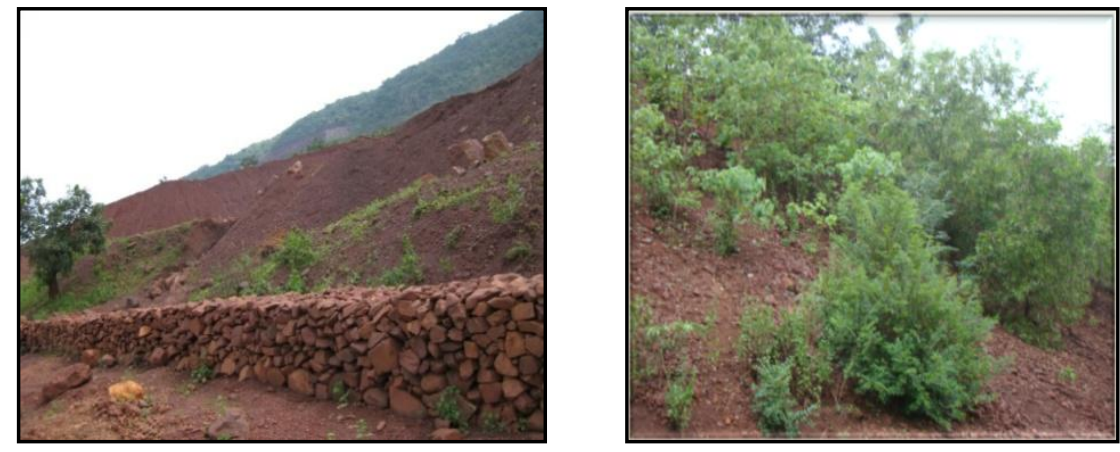

\title{
Field Observation
}

The field observation was hold on (22-26)march2010. I have made the survey over the some mining areas of this block and collect some G.P.S reading .I have collected the photographs of different morphological feature by digital camera.Following the (Fig -14) shows that different that type of picture view in the study area. These pictures are Figure 14: Photographs collected from different places in the study area.

bualubeda village, district of keonjhar, state of Orissa .other picture of geomorphological structure mines region is situated in this block. This area highly degraded for mining activities. Water pollution highly increased by the dust of open roust iron core.

\author{
Uses Software \\ - $\quad$ ARC GIS 9.3 \\ - $\quad$ ERDAS Imagine 9.0 \\ - $\quad$ Manifold 8.09 \\ - $\quad$ MS Office Professional 2007
}

\section{Results and Discussions}

A rapidly changing economic profile in mineral sector is putting a two-way pressure on environmental and social changes on the ground. This is leading a two way pressure on environmental institution. On one hand there is a growing public awareness demand for better environment management, while the level of non compliance of polluted industries is increasing. Rapid growth in industrial \& mineral sector is increasing workload for the environmental regulators to process the application, proper monitoring \& enforcing compliance and to respond to large number of public complaints. The ability of state institutions to manage the environmental \& social impacts of mining is also lacking.

The study area showing that total coverage of the land like vegetation, forest, mining activity zone and drainage cover area .but deeply see the total area is mining activity .that for the results is show the forest and vegetation land is going to decrease from previous production or planting. The total forest cover is $65 \%$ in 1975 ( Ref. toposheet 1975) but now we observe only $45 \%$ area are under forest cover(Ref.Recent satellite image) and also the increased mining activity(fig 08).

Other part of the way is shown that pollution is so much speeded that surrounding area is cover by dust .So the environment is highly polluted and not suitable for habitation. Malaria and other vector borne disease are spreading in that area.

\section{Conclusion}

The present study will be very useful in assessment of some change in land use pattern due to mining activity. The change in agriculture and forest land due to this activity will further help in actually finding out the adverse effect on vegetation of the area. This result of study will certainly be helpful in designing the mining or land use management plan and conservation of the study area which is a vital step in ecological planning .The proposed infrastructures facility shall be of use to people of the area. The roads, transportation facilities and rest sheds can be utilized by the community of the area. The revenue of the State Govt. shall be definitely increasing due to the enhanced production. The study area is surrounded by industries from all sides. The entire project area is devoid of any endangered flora and fauna. 


\section{References}

Proceedings Papers:

[1] K. Sarma, S.P.S. Kushwaha, coal mining impact on land use /land cover in jaintia hills district of Meghalaya, India using remote sensing and GIS technique. (2005) www.csre.iitb.ac.in/ csre/conf/wp-content/uploads/.../OS5_17.pdf

[2] P. Rabade, Environment impact assessment of land use planning around the leased limestone mine using remote sensing techniques. (2008)

[3] S.N. Paul, rapid environmental impact assessment and environmental management plan. (1867)

[4] CHILIKA DEVELOPMENT AUTHORITY state of Orissa (2010)

Books

[5] Directorate of Economics \& statistics(2010). Bhubaneswar Orissa

Chapters in Books:

[6] http://www.iiasa.ac.at/Admin/INF/OPT/Summer99/guenther_fischer.htm

[7] http://www.gocbse.com/posts/show/914257.htm

[8] www.vasundharaorissa.org

[9] http://unesdoc.unesco.org/images/0014/001449/144996m.pdf

[10] http://www.iiasa.ac.at/Admin/INF/OPT/Summer99/guenther_fischer.htm 